\title{
KAJIAN PERAN ELIT POLITIK DALAM KEBIJAKAN PANGAN: JEBAKAN IMPOR PANGAN PASCA REFORMASI
}

\author{
Wahyu Riawanti ${ }^{1}$
}

\begin{abstract}
This study aimed to unwrap the dynamic in policy making of food import, focusing in political elitess' interest during the period of 1999-2009. Every period was analized emphasizing the main characters of nepotism and rent seeking: (a) the general character of food policy, (b) regulation in prolonging its activity, and (c) policy actors/elites and the political party dominating the policy sector. Result of this reseach were mainly the difference of focus and characters on policy in 3 periods. Explanation of research finally answered as followed: (1) government elites are the main actors and they are mostly the policy makers from food institution, (2) the actors came from different political party and bring about the different agenda to be supported with regulation, and (3) food institution determined the rent-seeking activity through the same actors that also dominate the import area. The important evidence of this point was the "three pairs of name" that affiliated with (the same) political party, executed importing processes, and also influenced the regulation in very the same time.
\end{abstract}

Keywords: political economy, food import policy, policy elites, incremental policy.

\begin{abstract}
ABSTRAK
Studi ini mengkaji tentang dinamika kebijakan di Indonesia dengan fokus penelitian tentang kepentingan elit politik dalam formulasi dan implementasi kebijakan publik. Untuk mengetahui pola kepentingan elit politik selama kurun waktu 1999-2009, kajian ini dibagi menjadi tiga periode sesuai rejim pemerintahan dalam rentang waktu tersebut. Dalam setiap periode analisis ditekankan pada tiga pokok kajian yaitu (a) bagaimana karakter kebijakan suatu periode pemerintahan, (b) regulasi yang dilakukan untuk mengamankan kepentingan elites dan (c) aktor kebijakan dan partai politik yang berpengaruh. Hasil penelitian yang menunjukkan pola hubungan kerjasama mengamankan kepentingan dan dominasi aktor partai politik berdasarkan tiga periode tersebut kemudian menjawab pertanyaan whose finally interest counts. Penelitian ini menemukan bahwa: (1) elites pemerintah adalah aktor utama dalam kebijakan impor pangan yaitu didominasi oleh aktor dari lembaga pangan, (2) para aktor tersebut asal dari lembaga dan partai politik berbeda yang membawa dan mengakomodir kepentingan politiknya masing-masing melalui regulasi.
\end{abstract}

Kata kunci: ekonomi politik, elites kebijakan, kebijakan incremental.

\footnotetext{
${ }^{1}$ Peneliti, Otoritas Kompeten Keamanan Pangan Daerah (OKKPD) Daerah Istimewa Yogyakarta (DIY). Email: riawantiwahyu@gmail.com
} 


\section{PENDAHULUAN}

Trigger: sudah reformasi, masalah tidak juga selesai. Setelah tiga periode pemerintahan berbeda saat ini Indonesia masih terjebak dalam impor pangan yang penelitian ini berangkat dari kegelisahan terkait kompleksitas dalam proses formulasi kebijakan impor pangan di Indonesia. Kebijakan impor pangan seharusnya dibuat untuk memenuhi kepentingan publik dan didasari alasan pemenuhan hak atas pangan, bukan karena kepentingan politik dan daya tarik rente. Akan tetapi, banyaknya aktor pembuat kebijakan yang memiliki agendanya masing-masing menyebabkan adanya penekanan pada kepentingan yang berbeda. Dalam konteks kebijakan pangan, agenda utamanya ada pada pilihan antara swasembada produksi pangan atau pemenuhan stok pangan. Kedua hal inilah yang menjadi latar belakang gambaran proses formulasi kebijakan impor pangan di Indonesia.

Melihat aspek historis kebijakan pangan, maka kita harus melihat bahwa setiap pemerintah memiliki beban warisan dari pemerintah yang sebelumnya. Kegelisahan terkait kompleksitas formulasi kebijakan tersebut juga disebabkan oleh adanya ketimpangan akibat ketidaktepatan waktu dan peruntukan kebijakan impor pangan di Indonesia. Setelah melewati empat masa pemerintahan sejak Orde Baru, kebijakan pangan menyisakan masalah ketimpangan ekonomi dan sosial jika dilihat dari kondisi petani maupun kaum miskin kota. Dalam konteks pertanian dan perdesaan, ketimpangan dapat dilihat dari Nilai Tukar Petani (NTP) ${ }^{2}$ yang relatif kecil, jumlah pengangguran yang besar, dan tingginya angka kemiskinan, terutama di perdesaan (BPS, 2012).

Contoh pemberian beras miskin dan politisasi pangan telah dilakukan sejak adanya kebijakan pangan yang mengatasnamakan swasembada pangan dan pangan murah selama periode 19702000. Politisasi ini menyebabkan ketidakcukupan $^{3}$ produksi pangan pada masa sesudahnya.

\footnotetext{
${ }^{2}$ NTP adalah nilai ekonomi yang diterima oleh petani dibandingkan dengan nilai yang dibayarkanDengan klaim pertumbuhan ekonomi makro sebesar 6 persen, maka fakta tingginya angka pengangguran tersebut menunjukkan adanya kesalahan, seperti yang dinyatakan oleh Stiglitz (2012: 9) bahwa ada yang sistem yang salah ketika pertumbuhan ekonomi makro dapat dicapai, tetapi pada saat yang sama ketimpangan (inequality) juga semakin besar.

${ }^{3}$ Ketidakcukupan terkait dengan konsumsi beras per kapita dan produksi beras nasional. Konsumsi beras meningkat tajam karena adanya kebijakan beras murah dan berasisasi (perubahan makanan pokok) di sejumlah daerah yang tidak berbasis beras. Subsidi pemerintah untuk pupuk kimia diberikan dalam rangka peningkatan produksi dalam revolusi hijau pada akhir 1960-an.
} 
Serangkaian kebijakan pembebasan bea masuk impor beras pada 1998 menyebabkan munculnya ketergantungan impor. Obsesi tersebut juga berdampak pada marginalisasi petani produsen beras.

Politisasi impor beras dapat dilihat melalui Teori Elites. Paparan kerangka teoritis penelitian ini juga menjelaskan tentang policy making process dalam perspektif ekonomi politik untuk menjawab bagaimana dan atas kepentingan siapa suatu kebijakan diambil. Untuk melihat model hubungan aktor kebijakan digunakan Teori Elites Anthony Downs (1972) yang merupakan pengembangan dan kritik atas gagasan Charles Lindblom tentang konsep Rational Actor. Sebagai perbandingan, perspektif ekonomi politik Marx terutama dalam pandangan Nicos Poulantzas dipakai untuk melihat pendekatan kepentingan secara lebih tajam sehingga dapat menganalisis gejalanya. Bagian akhir bab ini menjelaskan kepentingan aktor dan melihat besarnya social loss sebagai dampak suatu kebijakan.

Menurut Joseph E. Stiglitz (2012), aktivitas para elit politik dalam konteks penyalahgunaan wewenang demi kepentingan kelompok yang konsepnya sangat dekat dengan kebijakan pangan di Amerika Serikat juga merupakan penyebab utama terjadinya ketimpangan di negara tersebut. Dalam bukunya yang berjudul The Price of Inequality, Stiglitz (2012) menjelaskan bahwa elite pemerintah yang hanya mewakili 1 persen dari penduduk AS menentukan kebijakan yang memengaruhi nasib 99 persen penduduk lainnya. Sementara itu, untuk kajian akademiknya, Tullock (2005) mengamati aktivitas lobi kebijakan pangan yang merupakan bagian dari kehidupan politik di negara maju, seperti Amerika Serikat. Meskipun tingginya kesadaran politik (political awareness) di negara maju menyebabkan masyarakatnya lebih intensif mengawasi dan mengadvokasi kebijakan menyangkut pangan, masyarakat AS masih juga merasa kecolongan karena dirugikan dengan hilangnya kepentingan kebijakan pangan.

Dengan melihat kompleksitas kebijakan dan menelusuri literatur studi kebijakan, penelitian ini berangkat dari hipotesis awal atau hipotesis kerja yang secara umum membawa pada kesimpulan sementara tentang bagaimana elite pemerintah adalah aktor utama dalam kebijakan impor pangan.

\section{METODE}

Rancangan penelitian yang dipergunakan dalam kajian ini adalah kualitatif deskriptif. Penelitian kualitatif 
bertujuan untuk memahami berbagai isu dan mencari jawab atas sejumlah pertanyaan dengan menguji berbagai setting sosial dan individu. Metode kualitatif ini dipilih untuk dapat menjabarkan realitas obyek penelitian tentang praktik kepentingan dalam kebijakan impor pangan untuk selanjutnya memberikan penafsiran dan pemaknaan yang mendalam dengan mengaitkan hasil analisis dan teori yang sudah ada. Diharapkan dengan metode kualitatif ini hasil penelitian akan memberikan kontribusi terhadap pengembangan teori dan konsep dari obyek kebijakan yang diteliti.

Dengan melihat kerangka berpikir dalam penelitian ini, diputuskan bahwa unit analisis dalam penelitian ini adalah pemetaan informasi dan data untuk memperoleh gambaran tiga periode pemerintahan yang berbeda. Sebelum sampai pada kerangka analisis tersebut telah dilakukan pemetaan secara historis bagaimana dinamika aktor dan kepentingan kebijakan impor pangan pada masa sebelumnya yaitu sejak era kolonial sampai reformasi. Karena setiap periode memiliki rentang waktu yang berbeda maka dilakukan modifikasi unit analisis yaitu dalam menentukan studi kasus, triangulasi, dan analisis siklus kebijakan dalam satu tahun. Pengambilan contoh kasus rangkaian impor pangan selama satu tahun dalam tiap pemerintahan yaitu tahun 2000-2001 untuk mewakili masa GusDur, tahun 2002-2003 untuk masa pemerintahan Megawati, dan tahun 2005-

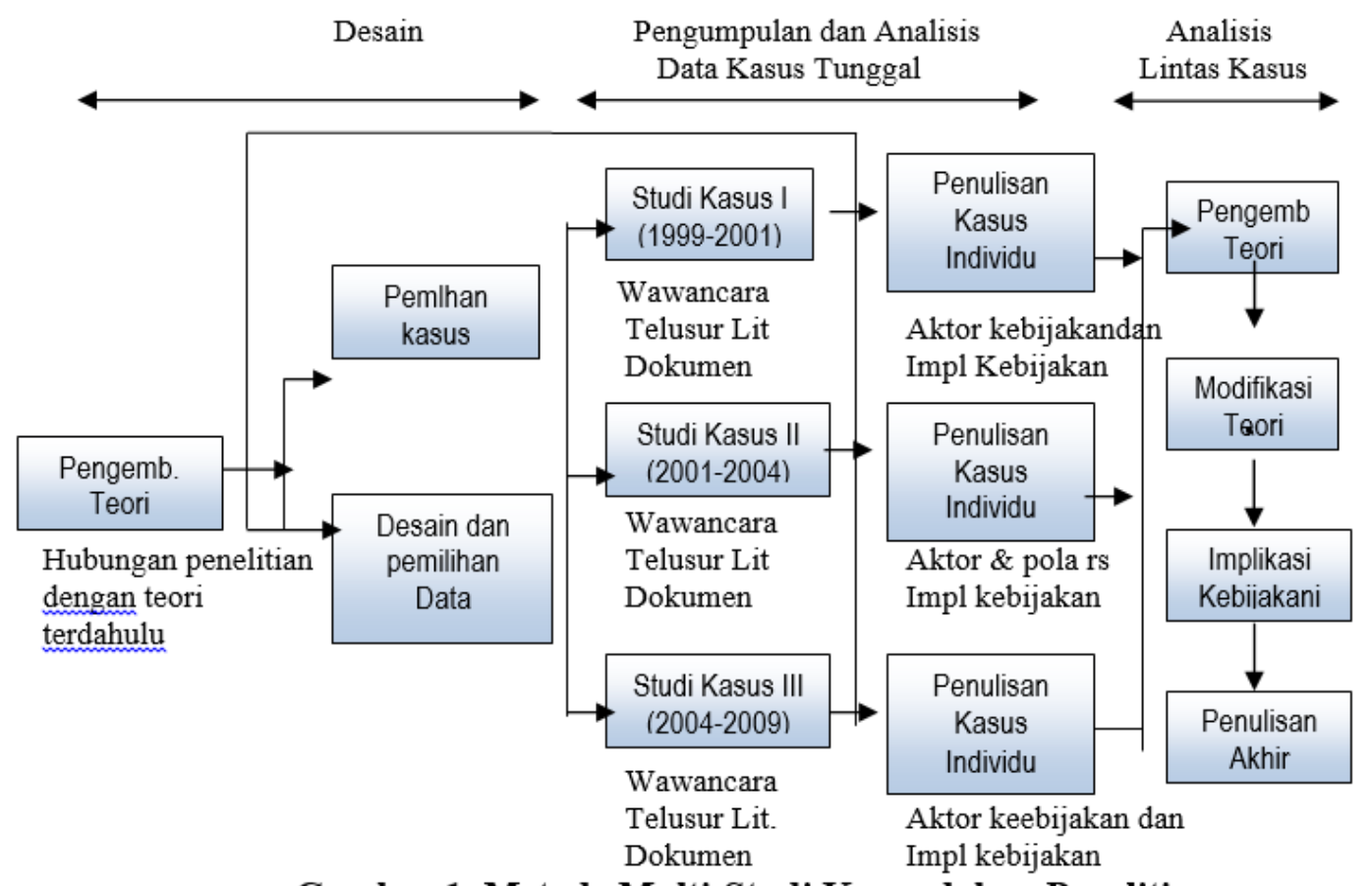

Gambar 1. Metode Multi-Studi Kasus dalam Penelitian 
2006 periode SBY. Hal ini dilakukan untuk mendapat gambaran dengan fokus kajian dan rentang waktu yang sama. Karena keterbatasan periode, pemilihan tahun dilakukan secara purposive.

Cara memperoleh data dan informasi dalam penelitian ini bersifat semi- investigatif. Terkait dengan hal jurnalisme investigatif sebagai bagian dalam penelitian ilmiah, dalam Bacon (2005) dijelaskan bahwa semua kegiatan yang diklasifikasikan sebagai penelitian dan pengembangan eksperimental ditentukan oleh 'keaslian', dan harus memiliki sisi 'investigasi' sebagai tujuan utama dan harus dapat memproduksi suatu hasil yang bermanfaat bagi ilmu pengetahuan dalam tataran teoritis maupun praktis. Untuk lebih jelasnya hal tersebut dijelaskan dalam definisi penelitiannya (Bacon, 2005) yaitu:

... any activity classified as research and experimental development is characterised by originality; it should have investigation as a primary objective and should have the potential to produce results that are sufficiently general for humanity's stock of knowledge (theoretical and/or practical) to be recognisably increased... (Bacon 2005: 148).

Penelitian ini menekankan pada tiga aspek yang disarankan oleh Lucinda Fleesan (2010) dalam melakukan investigasi yaitu (1) pengumpulan data dan dokumen untuk mendapatkan informasi (2) mendeteksi berbagai narasumber yang bisa menyediakan informasi (3) membuat kategorisasi untuk menentukan data relevan atau tidak untuk membuat analisa komprehensif suatu kasus. Data relevan yang didapat adalah merupakan informasi, bukti utama, pembanding dan pemberi keterangan tambahan.

\section{HASIL DAN PEMBAHASAN}

Revolusi Hijau yang Tidak Transparan

Harapan peningkatan produksi terjadi saat intensifikasi pertanian dilakukan melalui Revolusi Hijau pada awal tahun 60-an. Inisiasi program Revolusi Hijau kurang berjalan lancar pada masa Soekarno. Pada masa ini rencana pembangunan IRRI batal dilakukan dan Revolusi Hijau ditunda sampai pada pemerintahan Soeharto. Pemaksaan Revolusi Hijau sebenarnya dapat dilihat dari data statistik tentang tingginya angka impor dan rendahnya produksi beras di Negara Asia. Produktivitas padi di Indonesia, Philipina, dan Malaysia tidak sebesar di negara Asia daratan seperti India, Cina dan Myanmar.

Selama masa pemerintah kolonial inilah, negara Asia kepulauan disiapkan untuk mengembangkan tanaman perkebunan dan bukan tanaman pangan. 
Dengan demikian ide Revolusi Hijau memerlukan biaya tinggi untuk pembangunan infrastruktur irigasi.

Impor beras pada masa Orde Baru didominasi oleh pengusaha dalam lingkar keluarga Cendana yang membangun dinasti mafia pangan ini melalui pendekatan dengan birokrat (Aditjondro: 2002). Sepanjang periode ini Bulog bekerja sebagai perpanjangan tangan pemerintah dan tidak pernah tersentuh kasus hukum. Jumlah impor beras pada periode ini juga relatif kecil karena diuntungkan oleh Revolusi Hijau yang menjamin swasembada pangan setidaknya sepanjang tahun 1985-1995. Data produksi 1985-1995 menunjukkan jumlah produksi dengan produktivitas terbaik sepanjang sejarah pertanian Indonesia (Van der Eng, 2000).

Pada awal berdirinya Orde Baru, kondisi pangan di Indonesia masih mengalami keterpurukan sebagai akibat dari gagal panen yang dialami petani akibat kemarau berkepanjangan, inflasi yang membubung tinggi dan kelangkaan bahan pangan. Sebagai upaya jangka panjang, pemerintah mencanangkan program revolusi hijau yang merupakan desakan dari negara-negara maju (Wahono, 2011). Pemulihan ekonomi pada awal Orde Baru tersebut dilakukan atas prakarsa IMF dengan tujuan utama industrialisasi. Sesuai rencana (Repelita) pada dua periode pertama yaitu 19691979 pembangunan industrialisasi difokuskan pada industri ringan terutama tekstil.

Fokus pembangunan ini disertai dengan program awal intensifikasi pertanian tetapi peningkatan produksi pada awal tahun 70-an belum mencukupi kebutuhan dan pemerintah melakukan impor pangan dan tetap melakukan pengendalian harga pangan dan pengaturan impor pangan oleh Bulog.

Kebutuhan pangan pada masa Orde Baru meningkat tajam karena pangan menjadi fokus utama pembangunan pertanian pada jaman keemasan Orde Baru. Pengenalan teknologi melalui Revolusi Hijau pada masa ini menjadi harapan baru untuk menggandakan produktivitas padi. Hasil Revolusi Hijau yang mulai dinikmati pada akhir tahun 70-an ternyata hanya bertahan sekitar satu dekade dan selanjutnya produksi padi menurun drastis. Revolusi Hijau berhasil memenangkan hati rakyat Indonesia dengan tercapainya swasembada beras dan penghargaan FAO untuk Presiden Soeharto pada tahun 1984.

Meski demikian informasi tentang tingginya biaya yang dikeluarkan pemerintah untuk program ini tidak pernah transparan. Informasi yang tidak 
transparan tersebut terjadi karena tujuan terpenting Revolusi Hijau adalah swasembada beras at any cost. Untuk mendukung program tersebut, rejim Soeharto memberikan dana yang luar biasa besar dengan menyediakan subsidi khususnya untuk input pertanian dengan tujuan kemandirian produksi pangan. Proporsi biaya irigasi dalam Revolusi Hijau (RH) mencapai $60 \%$ dari total biaya teknis dan budidaya dari sejumlah 200 juta USD sebagai dana awal RH (World Bank, 1982).

Soeharto berkeyakinan bahwa ia akan mampu mempertahankan kekuasaanya, mendorong pertumbuhan ekonomi dan menjaga stabilitas politik (Suseno dan Suyatna, 2007). Program ini memang mampu mendorong terwujudnya swasembada pangan pada tahun 1984, dan tercapainya harga pangan murah terutama pada kaum miskin kota (KMK).

Dengan demikian, kepentingan pemerintah Soeharto berada di balik program Revolusi Hijau. Revolusi Hijau tidak hanya dipahami semata-mata secara teknis dengan meningkatnya produksi melalui "panca-usaha tani" tetapi merupakan mekanisme yang paling utama menuju pemaksaan pangan murah dengan biaya yang sebenarnya sangat tinggi. Revolusi Hijau juga disertai dengan masuknya korporasi internasional dan investasi asing penyedia input pertanian.

Awal program RH pada 1969 adalah kerjasama pemerintah Indonesia dengan PT. Ciba. McMichael (2009) secara khusus membuat penelitian tentang kapitalisasai pertanian di Asia pada masa pra Perang Dunia II sampai dengan masa Revolusi Hijau. Secara rapi paket RH dikemas dengan dukungan dana dari PT. CIBA yaitu dari korporasi agro-industri raksaasa AS. Kelak korporasi raksasa ini mensuplai sebagian besar input pertanian Indonesia dalam memenuhi swasembada beras melalui RH. Hal inilah yang kemudian menyebabkan ketergantungan pada sarana pertanian dari korporasi asing serta meninggalkan hutang tak terbayar sampai era reformasi.

Selama Revolusi Hijau kelompok petani gurem (peasant) sebenarnya tidak merespon keuntungan pada saat modernisasi pertanian terjadi. Penelitian Wahono (1998) menjelaskan bahwa rendahnya insentif ekonomi yang diterima petani padi menyebabkan pertanian skala kecil menjadi tidak menguntungkan. Revolusi Hijau meningkatkan produksi padi pada awal inisiasi, tetapi meninggalkan jejak berupa rendahnya produktivitas dan fenomena berupa kelompok petani kecil yang berhenti berproduksi. 
Peningkatan produksi selama Revolusi Hijau kemudian menjadi jargon politik untuk melawan derap revolusi merah yang makin mewabah di negaranegara terbelakang (Djafar, 2008). Untuk memajukan program ini, pemerintah melakukan pengawasan secara ketat terhadap pertanian rakyat. Upaya penyeragaman pangan semakin diperkuat dengan keluarnya UU No 5/1979 tentang Pemerintahan Desa yang kian mempersempit ruang aktualisasi masyarakat desa. Petani diwajibkan menggunakan cara-cara pertanian modern dengan pasca usaha tani sehingga sumber daya dan unsur-unsur pertanian tradisional hampir sepenuhnya ditinggalkan.

Melihat demikian kuat usaha pemerintah Orde Baru untuk mendorong dan membiayai Revolusi Hijau, tidak mengherankan program ini berhasil meningkatkan produksi. Program Revolusi Hijau pada awalnya dianggap tidak akan mengubah struktur sosial secara radikal, tetapi pada kenyataannya semakin membuat timpang struktur sosial masyarakat di pedesaan. Petani pemilik lahan memperoleh keuntungan karena berlipatnya jumlah produksi, sementara petani penggarap (peasant) semakin miskin karena kecilnya insentif ekonomi (Bachriadi dan Wiradi, 2011).
Diversifikasi pangan tidak berjalan lancar pada masa ini karena perhatian tersedot pada upaya pemajuan pangan. Ketergantungan terhadap baras kemudian dibarengi dengan mulai rusaknya sarana irigasi teknis pada awal 90-an sehingga produksi pangan yang mulai turun semakin tidak mencukupi kebutuhan nasional. Ditambah lemahnya struktur mikro di pedesaan, hal itu mengakibatkan Indonesia kembali menjadi negara netimporter pangan. Bahkan di akhir Soeharto berkuasa, pada 1998, tingkat impor beras Indonesia kembali pada angka $9 \%$, yang diikuti dengan angka impor komoditas pangan lainnya.

\section{Raskin 1998 Sebagai Turning Point}

Jika dilihat ke belakang, keputusan impor pangan dan Raskin yang dibuat pada masa pemerintahan sebelumnya tahun 1998-1999 dilakukan dengan pertimbangan masa darurat saat terjadi krisis ekonomi dan bencana El Nino. Pada masa darurat tersebut, pemerintah memang perlu bergerak cepat mengatasinya. Pada periode tersebut masalah utama yang harus diselesaikan adalah kenaikan inflasi dan krisis pangan (beras) yang tidak dapat menunggu (hasil wawancara, 2014). Namun selama tahun 2000 dan 2001 impor pangan skala besar serta Program Raskin tetap dilakukan 
meskipun masa krisis telah berlalu. Impor beras pada 1998 menjadi semacam titik tolak euforia sekaligus pemaksaan impor beras, terutama karena dua hal berikut: (a) Besarnya jumlah impor beras yang mencapai 2 juta ton per tahun untuk pemenuhan Program Raskin sejak tahun 1998; dan (b) Besarnya rente impor yang diperebutkan oleh importir dan Bulog karena pembebasan tarif impor tahun 1998 sesuai petunjuk IMF (Hiariej, 2012).

Program Raskin pada awalnya hanya akan dilakukan saat krisis saja, tetapi dengan kekuatan lobi, kebijakan Raskin masih berlaku sampai 2014. Namun banyak kajian dan penelitian yang menghasilkan temuan bahwa kebijakan Raskin berdampak pada ketergantungan masyarakat miskin dan bias pada kebijakan yang berbasis produksi (Hutagaol, 2007). Hasil wawancara dengan RR berikut mengonfirmasi hal tersebut.

“... Raskin harus dilihat (dari sisi) sejarahnya, pertama kali dilakukan oleh pemerintah pada tahun 1998 dengan tujuan utama keluar dari krisis, tidak untuk selamanya. Pada awalnya program ini kami maksudkan dengan tujuan we spend money for they who work. Pada tahun-tahun berikutnya program ini tetap dilanjutkan meski jelas program salah sasaran karena sudah diputuskan untuk no subsidy on commodity ... sebenarnya Raskin 2 juta ton itu, ya supaya bisa impor beras ..." (RR, Jakarta, 11 September 2014).

Massa Transisi: Tahun 1991-2001

Formulasi kebijakan pasca reformasi terasa lebih demokratis dibandingkan dengan proses formulasi kebijakan yang sama pada masa Orde Baru. Pada masa pasca reformasi ini terjadi proses transisi yang menyebabkan banyak pejabat merasa ketakutan jika institusinya akan dihilangkan karena adanya perampingan kabinet. Karena isu kedekatan inilah, masa pemerintahan Gus Dur terganjal isu korupsi Bulog yang menyeret namanya dan berujung pada pemakzulan pada tahun 2001. Kasus ini kemudian dikenal sebagai Bulog-gate I.

Meskipun melakukan banyak pembenahan secara kelembagaan, periode ini masih mewarisi banyak ciri pemerintah Orde Baru dalam hal sistem politik di Indonesia. Ciri yang tampak sepanjang 1999-2001 adalah adanya dominasi birokrasi dalam proses perumusan kebijakan. Kondisi tersebut menimbulkan mekanisme patron-client dalam proses formulasi kebijakannya.

Formulasi kebijakan sepanjang periode pemerintahan Gus Dur yang sekaligus menjadi ciri kebijakan era Gus Dur adalah fenomena Raskin yang dilanjutkan menjadi program langgeng dan politisasi Bulog-gate yang merupakan 
pertarungan politik Golkar/PDIP dan PKB. Dalam kurun waktu tersebut, kebijakan pemerintah justru telah menciptakan landasan rente impor pangan karena besarnya jumlah profit yang menjanjikan. Periode ini pula dimanfaatkan elite untuk menyesuaikan diri dengan sistem yang berubah pasca reformasi, yaitu dengan munculnya pemain impor baru dari kalangan politisi Golkar yang jauh lebih berpengalaman.

\section{Masa Pelarangan Impor: Tahun 2001- 2004}

Sejak awal 2002 data angka impor sarat dengan manipulasi. Selanjutnya pemerintah mengganti status Bulog menjadi perusahaan umum untuk melegalkan orientasi keuntungan Bulog. Sepanjang tahun 2001-2004 pemerintah melanggengkan kembali program Raskin meskipun para ahli ekonomi dan pembangunan telah mulai mengevaluasi dan mengkritik program ini.

Ciri utama periode pemerintahan Megawati adalah masalah inkonsistensi data, munculnya "wajah" dan status baru Bulog, serta fenomena aktor pemain lama dalam wilayah kebijakan impor beras. Sepanjang tahun 2001-2004 pemerintah melakukan pembatasan impor untuk menunjukkan kehati-hatian lembaga pangan baru, sekaligus melegalisasi impor lewat status Bulog sebagai perusahaan umum. Sepanjang periode ini data/angka hanya dipakai untuk tujuan politis dan wajah baru Bulog justru dimaksudkan untuk mencari profit dengan lebih aman.

$$
\text { Penanganan kasus Bulog-gate I }
$$

menjadi titik awal pemerintahan Megawati. Rentannya masalah Bulog terbukti dengan bergulirnya kasus Buloggate II. Sebagai akibat dari kasus tersebut, nasib Akbar Tanjung hampir berakhir. Ranah kebijakan impor pangan menjadi medan partai politik untuk menunjukkan eksistensinya saat menghadapi kemelut Bulog-gate II tersebut. Pada titik ini Partai Golkar sukses melakukan lobi politik yang menyebabkan PDIP berbalik mendukung Golkar dan menolak pembentukan Pansus Bulog-gate II (Ambardi, 2009).

Temuan utama dalam periode ini adalah: Pertama, kenyataan inkonsistensi data menunjukkan bahwa pemerintah menyembunyikan angka impor pangan, sedangkan di saat yng sama BUMN dan birokrasi harus melayani kepentingan elite politik. Konfirmasi kesimpulan ini adalah adanya inkonsistensi data paling signifikan karena kepentingan pemerintah yang terjadi sepanjang 2002-2004.

Kedua, ciri kebijakan dan peran aktor yang merupakan temuan penelitian pada bab ini adalah kebijakan impor 
pangan dikendalikan dan menjadi pertarungan antar partai politik. Buloggate adalah pertarungan politik antara PKB dan Golkar/PDIP. Sementara itu, ketika birokrat harus melayani kepentingan elite politik, salah satu langkah yang dilakukan adalah dengan menerbitkan surat keputusan Menteri Keuangan yang ganda. Hal ini menjadi perpanjangan tangan berupa mafia pangan dengan jaringan dan cara kerja yang sangat rapi. Sepanjang tahun 2001-2004 tersebut kasus impor beras ilegal paling sering terjadi yaitu justru saat pemerintah berani mengambil perintah pelarangan impor. Menariknya, pelaku bisnis dan impor beras justru didominasi oleh pengusaha asal partai politik dan terjadi pelanggaran impor pangan oleh Kabulog dengan jumlah kerugian negara yang paling besar.

Ketiga, elit politik sepanjang periode ini membuat jejaring dengan cara langsung melalui afiliasi partai maupun tidak langsung. Hubungan secara langsung adalah melalui kedekatan dalam partai politik Golkar dan PDIP dengan adanya tiga pasang nama kembar Golkar, yaitu WP1, WP2, SN, SL, NH dan WH. Sementara itu, hubungan tidak langsung dilakukan dalam kepengurusan PSSI yang terbukti dengan kedekatan $\mathrm{NH}$ sebagai
Kepala INKUD dan MZ sebagai pejabat bea cukai.

\section{Basis Produksi Setengah Hati: Periode Tahun 2004-2009}

Temuan utama dalam periode ini adalah bahwa elite kebijakan melalui perannya dalam formulasi kebijakan justru menghasilkan keputusan yang menjadikan kebijakan terkait pangan semakin jauh dari agenda kedaulatan pangan. Penjelasan dalam bab ini juga merupakan pembuktian indikator yang menjelaskan kuatnya peran aktor kebijakan dalam aktivitas impor sepanjang 2004-2009. Pada akhirnya aktor kebijakan menegasikan gagasan kembali ke basis produksi meskipun pemerintah mengklaim swasembada pangan pada tahun politik 2008

Peran aktor dalam melanggengkan kepentingannya tersebut adalah melalui hal-hal berikut: pertama, komitmen pemerintah untuk tidak mengintervensi Bulog tetapi justru menyebabkan lembaga ini menjadi sangat superior. Selanjutnya yang terjadi adalah justru aktor kebijakan panganlah yang secara masif melakukan pelanggaran dalam mekanisme impor pangan. Formulasi impor pangan pada periode 2004-2009 yang sedianya berbasis produksi tidak sepenuhnya terjadi. Hal ini dibuktikan dengan pertimbangan 
kebijakan impor pangan yang menunjukkan dominasi partai politik penguasa.

Temuan kedua adalah peran dan partisipasi anggota legislatif yang lebih dinamis, tetapi tidak menunjukkan hasil yang signifikan dalam menyelesaikan blunder impor pangan dan kedaulatan pangan. Impor pangan dan klaim swasembada pangan hanyalah bertujuan untuk kepentingan elite. Hal ini dapat dilihat dari lemahnya fungsi pengawasan DPR melalui hak angket maupun interpelasi dan adanya hubungan keluarga atau kesamaan afiliasi antara anggota dewan dan pengusaha/importir pangan.

Ketiga, untuk memastikan kepentingan elite tetap terjamin, dilakukan usaha untuk melanggengkan kepentingannya dalam kebijakan impor pangan. Usaha tersebut adalah dengan melakukan rekrutmen dan promosi jabatan yang berada pada satu otoritas dalam dominasi/kapling lembaga teknis dan menerapkan konsep Hire and Fire. Pencopotan dan penggantian dengan mudah dilakukan untuk kepentingan rents. Bongkar pasang itu melanggengkan kepentingannya sehingga menyebabkan besarnya social loss sebagai akibat aktivitas penyalahgunaan wewenang dalam jangka panjang. Ketika kebijakan pangan melalui impor pangan dikendalikan oleh para elite demi kepentingan rents, maka ujung dari akibatnya adalah ketimpangan.

Pengamatan dan studi atas tiga periode pemerintahan tersebut juga menghasilkan pemetaan dinamika kebijakan untuk mengetahui potensi dan dominasi partai politik dalam melanggengkan kepentingannya. Hal ini dijelaskan melalui afiliasi partai dan karier politik setiap elite secara historis. Dari gambaran tersebut dapat dilihat hubungan bisnis yang telah terjalin sebelumnya dan memudahkan regulasi saat eksekusi impor.

\section{SIMPULAN}

Keputusan impor beras sepanjang tahun 1999-20009 bermuara pada kepentingan politik melalui praktik rentseeking. Dengan masing-masing karakter dalam tiga pemerintah berbeda, kepentingan tersebut dieksekusi melalui tiga indikator utama yaitu (a) karakter kebijakan pangan, (b) regulasi dalam melanggengkan impor pangan, dan (c) aktor kebijakan dan partai politik.

Dalam pembahasan sebelumnya telah dijelaskan bahwa keputusan impor pangan yang dilakukan sepanjang tiga periode tersebut lebih mengutungkan pelaku impor pangan yaitu Bulog dan importir swasta. Kedua eksekutor impor 
ini didominasi oleh elites partai politik terutama partai politik yang berkuasa. Partai politik tersebut memiliki wewenang dalam menentukan impor pangan melalui lobby para aktor legislatif dan intervensi ke dalam institusi Bulog maupun regulasi pemerintah. sebelumnya yang kemudian memudahkan regulasi pada saat eksekusi impor.

Hasil penelitian menjelaskan bentuk dan pola hubungan kerjasama antar elit politik yang beragam yaitu Individual Linear, Organizational Corporatism, dan Individual Triangle

Tabel 1. Perbandingan Indikator Kebijakan Pangan Tiga Pemerintahan 1999 -2009

\begin{tabular}{|c|c|c|c|c|}
\hline & & \multicolumn{3}{|c|}{ PEMERINTAHAN } \\
\hline No & Indikator & $\begin{array}{l}\text { Gus Dur } \\
1999-2001\end{array}$ & $\begin{array}{c}\text { MEGA } \\
2001-2004\end{array}$ & $\begin{array}{c}\text { SBY } \\
2004-2009\end{array}$ \\
\hline 1 & \multicolumn{4}{|c|}{ Kinerja atas kebijakan pangan } \\
\hline & Produksi & $\begin{array}{l}\text { Penurunan sejak } \\
\text { 1990-an pasca RH }\end{array}$ & $\begin{array}{l}\text { Penurunan produksi } \\
\text { dan pelarangan impor }\end{array}$ & $\begin{array}{l}\text { Klaim swasembada } \\
\text { pada } 2008\end{array}$ \\
\hline & Impor & $\begin{array}{l}\text { Surge impor } 1998 \\
\text { dan } 2000\end{array}$ & $\begin{array}{l}\text { Surge impor } \\
\text { impor beras ilegal }\end{array}$ & Pengaturan waktu impor \\
\hline & Raskin & Dïnisiasi sejak 1998 & $\begin{array}{l}\text { Jumlah meningkat } \\
\text { sejak } 2003\end{array}$ & $\begin{array}{l}\text { Jumlah raskin } \\
\text { diturunkan pada } 2007\end{array}$ \\
\hline \multirow[t]{3}{*}{2} & Regulasi & & & \\
\hline & Kuota & $\begin{array}{l}\text { Bebas impor sampai } \\
1999\end{array}$ & $\begin{array}{l}\text { Kuota berupa perintah } \\
\text { impor }\end{array}$ & $\begin{array}{l}\text { Kuota berupa perintah } \\
\text { impor kecuali b khusus }\end{array}$ \\
\hline & $\begin{array}{l}\text { BM dan kebjkn } \\
\text { Turunan }\end{array}$ & $\begin{array}{l}\text { Bea masuk } 0 \% \\
\text { menjadi } 30 \% 2000\end{array}$ & $\begin{array}{l}\text { Inkonsistensi data, } \\
\text { SKep Ganda }\end{array}$ & $\begin{array}{l}\text { Hire and Fire, peru- } \\
\text { bahan syarat importir }\end{array}$ \\
\hline 3 & \multicolumn{4}{|c|}{ Aktor Kebijakan dan Partai Politik } \\
\hline & Aktor & SP,WP & NH-WH, SN-SL, WP-WP1 & SN, SL WP \\
\hline & Parpol & Golkar, PKB & Golkar, PDIP & Golkar,PKS \\
\hline & Pola kerjasama & $\begin{array}{l}\text { Individual Linear \& } \\
\text { Individual Triangle }\end{array}$ & $\begin{array}{l}\text { Individual Linear \& } \\
\text { Individual Triangle }\end{array}$ & $\begin{array}{l}\text { Individual Triangle \& } \\
\text { Org Corporatism }\end{array}$ \\
\hline 4 & \multicolumn{4}{|l|}{ Faktor eksternal } \\
\hline & $\begin{array}{l}\text { Institusi } \\
\text { Internasional }\end{array}$ & $\begin{array}{l}\text { IMF dan Structural } \\
\text { Adjustment prog. }\end{array}$ & $\begin{array}{l}\text { Resep Raskin WB dan } \\
\text { Privatisasi }\end{array}$ & $\begin{array}{l}\text { WTO dan tekanan } \\
\text { eksportir pangan }\end{array}$ \\
\hline & MNCs & $\begin{array}{l}\text { Menguasai input } \\
\text { pertanian sjk } 60 \text { an }\end{array}$ & Worls Food Regime & $\begin{array}{l}\text { MNCs to feed the } \\
\text { world }\end{array}$ \\
\hline
\end{tabular}

Sumber: Hasil penelitian

Kekuatan elit partai tersebut dijelaskan melalui penjelasan penguasaan mekanisme impor dari proses pengusulan sampai pelaksanaan impor. Hal ini dijelaskan dalam pembahasan mengenai afiliasi partai dan secara historis karir politik masing masing elit. Dari pembahasan tersebut dapat dilihat hubungan bisnis yang sudah terjalin
Alliances. Pola Organizational atau hubungan antar instansi dilakukan secara sistematis di bawah kendali partai-partai penguasa sepanjang tahun 1999 - 2009. Faktanya, para pelaku pelanggaran dan penyalahgunaan wewenang dalam kasus impor beras Vinafood berafiliasi pada tiga organisasi yaitu Golkar-PDIP, Bulog/INKUD dan PSSI. Pola individual 
yaitu hubungan melalui pihak ketiga atau perantara dilakukan untuk memperlancar hubungan antar instansi.

Pola tersebut tidak hanya khas Indonesia karena juga terjadi di banyak negara berkembang. Meskipun demikian pola di Indonesia termasuk unik yaitu bermuara pada usaha untuk mendapatkan lisensi yang diterbitkan oleh pemerintah dalam bentuk kuota dan perintah impor. Penelitian yang dilakukan oleh Hausken (2009) mengungkapkan bahwa kualitas pemerintah yang buruk akan menyebabkan perilaku korupsi sebagai salah misuse sering terjadi, yang kemudian menyebabkan inefisiensi biaya tinggi yang menghambat pertumbuhan ekonomi.

Hasil tersebut sesuai dengan pernyataan Blackburn (2009) yang menjelaskan bahwa pola dan dampak korupsi tidak selalu sama di masingmasing negara, tergantung pada sistem politik dan ekonomi. Ringkasnya, sistem yang 1999-2009 yang masih memungkinkan terjadi kepentingan politik dalam eksekusi impor. Karena dalam melakukan kegiatannya importir membutuhkan surat keterangan dan lisensi kuota impor. Hal ini menyebabkan lobby politik yang sistem yang mengamankan kepentingan elit politik dengan mengamankan lisensi yang seharusnya diberikan secara gratis.

\section{DAFTAR PUSTAKA}

Aditjondro, George J. 2002. Large dam victims and their defenders: the emergence of an anti-dam movement in Indonesia dalam The Politics of Environment in Southeast Asia: Resources and Resistance. Asia Research Centre, Murdoch University, Western Australia

Ambardi K. 2009. Mengungkap Politik Kartel: Studi Tentang Sistem Kepartaian di Indonesia era Reformasi. Jakarta. Kepustakaan Populer Gramedia.

Bachriadi, Dianto dan Gunawan Wiradi. 2011. Enam Dekade Ketimpangan: Masalah Penguasan Tanah di Indonesia. Agrarian Resource Centre, Bina Desa dan KPA

Bacon, W. 2005. Journalism as Research. Australian Journalism Review, 28 (2): pp: $147-157$

Bahari, Syaiful. 2002. Petani dalam perspektif moral ekonomi dan politik Ekonomi dalam Menuju Keadian Agraria. Diterbitkan oleh Akatiga bekerja sama dengan IPB.

Blackburn, Keith. 2009. Corruption and Rent-seeking: Why is corruption less harmful in some countries than others?. Journal of Economic Behavior and Organization. Vol 72, 2009 pp: 797-810. 
BPS. 2012. Statistik Pertanian: Tenaga Kerja Komoditas Pertanian dan NTP Dalam Angka. Diterbitkan oleh Biro Pusat Statistik. Jakarta

Djafar, M. 2008. Pedesaan Sebagai Sumber Pangan: Dalam Cengkeraman Gurita Neo-liberalisme dalam Francis Wahono, Dwi Astuti dan Sabiq Carebesth (eds) Ekonomi Politik Pangans: Dari Ketergantungan ke Kedaulatan. Bina Desa Cindebooks: 97-101.

Downs, Anthony. 1972. Up and Down With Ecology. Journal of Political Economy. Vol. 65 No. 2. April 1972. PP 68-85.

Fleeson, L. 2010. Dig Deep and Aim High: A Training Model for Investigative Journalism. $\leq \mathrm{www}$. Merril.umd.edu>

Hausken, Kjell. 2012. On The Inappropriateness of Collective Rent Seeking Analysis Within-Group and Between-Group Efforts. Economics Letters Vol 116 (2012). PP 504-507

Hutagaol, M. Parulian dan Alla Asmara. 2008. Analisis Efektivitas Kebijakan Publik Memihak pada Masyarakat Miskin: Studi Kasus Pelaksanaan Program Raskin di Jawa Barat. Jurnal Agro Ekonomi Vol. 26. No 2 Oktober 2008, IPB.

Hiariej, Eric. 2012. Globalisasi, Kaptalisme dan Perlawanan. Institute of International Studies. Jurusan Hubungan Internasional. Fakultas Ilmu Sosial dan Ilmu Politk (IIS). Universitas Gadjah Mada.
Kano, Hiroyoshi. 2008. Indonesian Exports, Peasant Agriculture and The World Economy 1850 - 2000. National University Singapore.

McMichael. 2009. A food Regime Genealogy. The Journal of Peasant Studies. Vol. 36, No. 1, January 2009, 139-169.

Stiglitz, Joseph. E. 2012. The Price of Inequality. Norton and Company.

Suseno, Djoko dan Hempri Suyatna. 2007. Mewujudkan Kebijakan Pertanian yang Pro-Petani. Jurnal Ilmu Sosial dan Ilmu Politik. Vol. 10, Nomor 3, Maret 2007

Tullock, G. 2005. Public Goods, Redistribution and Rent Seeking. George Mason University, USA. The Locke Institute.

Van der Eng, Pierre. 2000. Food for Growth: Trends in Indonesia's Food Supply

1880-1995. The Jornal of Interdisciplinary History Vol. 30. No. 4 pp 581-616

World Bank. 1982. Green Revolution: Food Productivity And Its Dinamc in Asia. Report Paper published by Rockefeler Foundation.

Wahono, Francis. 2011. Kedaulatan Pangan: Agri-culture bukan Agribusiness: Mensiasati Negara Lupa Bangsa dalam Francis Wahono, Dwi Astuti dan Sabiq Carebesth (eds) Ekonomi Politik Pangan. Kembali ke Basis: Dari Ketergantungan ke Kedaulatan.. Bina Desa dan Cindebooks. 
Wahono, Francis. 1998. The Socioeconomic Impact of The Green Revolution on Asset-Class Relations in: A Case Study in Two Javanese
Villages. Disertasi School of Business Faculty of Law and Management. La Trobe University Bunduora Voctoria Australia. Tidak dipublikasikan 